Research Article

\title{
Phytochemical Analysis and Study of Antioxidant, Anticandidal, and Antibacterial Activities of Teucrium polium subsp. polium and Micromeria graeca (Lamiaceae) Essential Oils from Northern Morocco
}

\author{
Taoufiq Benali, ${ }^{1,2}$ Khaoula Habbadi, ${ }^{3}$ Abdelhakim Bouyahya $\left(\mathbb{D},{ }^{4}\right.$ Abdelmajid Khabbach, ${ }^{5}$ \\ Ilias Marmouzi (D), ${ }^{6}$ Tarik Aanniz, ${ }^{7}$ Houda Chtibi, ${ }^{2}$ Hanae Naceiri Mrabti, ${ }^{8}$ \\ El Hassan Achbani, ${ }^{3}$ and Khalil Hammani ${ }^{2}$ \\ ${ }^{1}$ Environment and Health Team, Polydisciplinary Faculty of Safi, Cadi Ayyad University, Marrakesh, Morocco \\ ${ }^{2}$ Laboratory of Natural Resources and Environment, Polydisciplinary Faculty of Taza, Sidi Mohamed Ben Abdellah University, \\ B.P.: 1223, Taza-Gare, Taza, Morocco \\ ${ }^{3}$ Laboratoire de Recherche et de Protection des Plantes URPP-INRA-Meknès, Meknès, Morocco \\ ${ }^{4}$ Laboratory of Human Pathologies Biology, Department of Biology, \\ Faculty of Sciences, and Genomic Center of Human Pathologies, Faculty of Medicine and Pharmacy, \\ Mohammed V University in Rabat, Rabat, Morocco \\ ${ }^{5}$ Laboratory of Materials, Natural Substances, Environment and Modeling, Polydisciplinary Faculty of Taza, \\ Sidi Mohamed Ben Abdellah University, B.P.: 1223, Taza-Gare, Taza, Morocco \\ ${ }^{6}$ University Mohammed $V$ in Rabat, Faculty of Medicine and Pharmacy, Laboratory of de Pharmacology et Toxicology, \\ Rabat Instituts, BP 6203, Rabat, Morocco \\ ${ }^{7}$ Medical Biotechnology Laboratory (MedBiotech), Rabat Medical \& Pharmacy School, Mohammed V University in Rabat, \\ Rabat 6203, Morocco \\ ${ }^{8}$ Laboratory of Pharmacology and Toxicology, Bio Pharmaceutical and Toxicological Analyzes Research Team, \\ Faculty of Medicine and Pharmacy, Mohammed V University in Rabat, BP 6203, Rabat, Morocco
}

Correspondence should be addressed to Abdelhakim Bouyahya; boyahyaa-90@hotmail.fr

Received 13 November 2020; Revised 5 February 2021; Accepted 1 March 2021; Published 15 March 2021

Academic Editor: Letizia Angiolella

Copyright (C) 2021 Taoufiq Benali et al. This is an open access article distributed under the Creative Commons Attribution License, which permits unrestricted use, distribution, and reproduction in any medium, provided the original work is properly cited.

The protection of agricultural crops and the preservation of the organoleptic and health qualities of food products represent a major challenge for the agricultural and agro-food industries. Essential oils have received greater attention as alternatives to replace the control strategies based on pesticides against phytopathogenic bacteria and synthetic compounds in food preservation. The aims of this work were to study the chemical composition of Teucrium polium subsp. polium and Micromeria graeca essential oils and to examine their antioxidant and antimicrobial effects. To carry out this work, the chemical composition of the essential oil was determined using gas chromatography (GC) with the detection feature of mass spectrometry (MS). Subsequently, the antioxidant activity was investigated by DPPH and FRAPS assays. The antimicrobial effect was studied against phytopathogenic and foodborne pathogenic bacteria using the disc and the microdilution methods. Our results showed that GC-MS analysis of EOs allowed the identification of 30 compounds in T. polium EO (TPpEO), while 5 compounds were identified in $M$. graeca EO (MGEO). TPpEO had as major compounds $\beta$-pinene (19.82\%) and germacrene D (18.33\%), while geranial (36.93\%) and z-citral (18.25\%) were the main components of MGEO. The most potent activity was obtained from MGEO ( $\left.\mathrm{IC}_{50}=189.7 \pm 2.62 \mu \mathrm{g} / \mathrm{mL}\right)$ compared to TPpEO $\left(\mathrm{IC}_{50}=208.33 \pm 3.51 \mu \mathrm{g} / \mathrm{mL}\right.$. For the FRAP test, the highest reducing power was obtained from $1.32 \pm 0.1 \mathrm{mg}$ AAE/g of TPpEO compared to MGEO 0.51 $\pm 0.13 \mathrm{mg}$ AAE/g of EO. Both EOs exhibited varying degrees of antibacterial activities against all the tested strains with inhibition zones in the range of $9.33 \pm 0.57 \mathrm{~mm}$ to $>65 \mathrm{~mm}$ and MIC values from 0.19 to $12.5 \mathrm{mg} / \mathrm{mL}$. However, MGEO exhibits an interesting anticandidal effect with inhibition zone $44.33 \pm 0.57 \mathrm{~mm}$. The findings of this research establish the riches of EOs on volatile compounds, their important antioxidant activity, and their antimicrobial effect against the bacteria tested. 


\section{Introduction}

The security of agricultural crops and both organoleptic and health qualities of food products represent a main defiance for the agricultural and agro-food industries $[1,2]$. The control of the problems caused by phytopathogenic bacteria is based on use of pesticides and antibiotics with potential side effects on the environment and living beings. Such chemicals are not very biodegradable and represent a risk of developing antibiotic resistance, which inspired the European Union to limit their use $[3,4]$. On the other hand, the preservation of food products is assured by synthetic compounds called "food additives," presented potential side effects on the consumer [5-7]. The plant extracts and essential oils as antioxidant and antimicrobial agents are focused to overcome these problems and to satisfy the improved demand for more natural solutions.

For a long time, different cultures and civilizations worldwide have been using plants as drugs to treat numerous diseases [8-10]. The essential oils (EOs) are among the natural products of great interest in food, cosmetic, and pharmaceutical industries due to their antioxidant and antibacterial [11-18], antifungal [19-25], antiparasitic $[6,26]$, insecticidal [27-31], and anticancer activities [32-34].

Morocco by its biogeographical position is characterized, on the one hand, by ecological and floristic diversities and, on the other hand, by a long tradition and expertise in the use of plant medicines [35-37]. Previous works in some regions of Morocco have shown that the Moroccan pharmacopoeia is dominated mainly by Lamiaceae [38-41]. A great economic importance is given to many of their species due to their EO production [42] and their traditional use $[40,43,44]$. In recent decades, in the goal to valorize the Moroccan Lamiaceae species, previous researchers have evaluated the antioxidant and antimicrobial activities of essential oils of many plants [45-49]. In this order, our study focused on two species of Lamiaceae, Teucrium polium subsp. polium and Micromeria graeca, locally known as "Jaâda" and "Bakolt'nhal," respectively. These species have been strongly used in Moroccan traditional medicine [38-40, 44, 50].

To the best of our knowledge, no reports on the variation of essential oil composition and biological activities of these plants collected from the Province of Taza, Northern Morocco, are available. Therefore, the objectives of this study were the identification of volatile compounds of hydrodistilled EOs of T. polium and M. graeca and the investigation of their antioxidant and antimicrobial activities.

\section{Materials and Methods}

2.1. Collection of Plants and Isolation of Essential Oils. Both plants were collected in April 2016 from the Province of Taza, Northern Morocco (004 $52.607^{\prime} \mathrm{N}, 004^{\circ} 01.190^{\prime} \mathrm{W}$ and $\left.34^{\circ} 09.825^{\prime} \mathrm{N}, 004^{\circ} 09.850^{\prime} \mathrm{W}\right)$. The identification of plants was achieved by Pr. Ennabili Abdeslam and Dr Khabbach
Abdelmajid in the Natural Resources and Environment Laboratory of the Polydisciplinary Faculty of Taza, Sidi Mohamed Ben Abdellah University of Fez, where a voucher plant specimen has been deposited for future reference (FPT-LRNE-73: Teucrium polium subsp. polium and FPTLRNE-72: Micromeria graeca). The aerial parts of the plants were dried at room temperature. Then, the plant sample (100 g) was subjected to hydrodistillation using a Clevengertype apparatus for $4 \mathrm{~h}$. The essential oil was stored at $4^{\circ} \mathrm{C}$ until use.

2.2. Gas Chromatography-Mass Spectrometry (GC-MS) Analysis. The chemical composition of EOs was analyzed according the conditions described in our previous works $[51,52]$. For each compound, the Kovats retention index (RI) was calculated relative to a standard mix of n-alkanes between C9 and C31 (Sigma-Aldrich Co.). Identification of constituents was performed by comparison of RI and MS spectra with those reported in the literature and by computer matching with standard reference databases (NIST98, Wiley275, and CNRS libraries).

\subsection{Antioxidant Activity}

2.3.1. Free Radical Scavenging Activity. The radical effect of EOs was evaluated using the radical 2.2-diphenyl-1-picrylhydrazyl (DPPH) as reported by Benali et al. [52] and Huang et al. [53], with some modifications. In brief, the DPPH solution ( $0.2 \mathrm{mM}$ in methanol) was prepared. Then, $2.5 \mathrm{~mL}$ of test sample at different concentrations $(2.5-100 \mu \mathrm{g} / \mathrm{mL})$ was added to $0.5 \mathrm{~mL}$ of DPPH solution, and the absorbance of samples was measured at $517 \mathrm{~nm}$ after $30 \mathrm{~min}$. Ascorbic acid and Trolox were used as positive controls.

The calculation of the antioxidant activity was done according to the following formula:

$$
\text { DPPH scavenging activity }(\%)=\left[\frac{\left(A_{0}-A_{s}\right)}{A_{0}}\right] * 100 \text {, }
$$

where $A_{\mathbf{0}}$ is the absorbance of the negative control and $\mathbf{A}_{\mathbf{s}}$ is the absorbance of the test sample at $30 \mathrm{~min}$. The test was carried out in triplicate, and the $\mathrm{IC}_{50}$ values were reported as mean \pm SD.

2.3.2. Reducing Power of Ferric Ions. The reducing activity of EOs was determined according to Benali et al. [52] and Oyaizu [54]. The mixture of the sample $(1 \mathrm{~mL})$, the phosphate buffer ( $2.5 \mathrm{~mL}, 0.2 \mathrm{M}, \mathrm{pH} 6.6)$, and the potassium ferricyanide $(2.5 \mathrm{~mL})$ was prepared. After incubation for $20 \mathrm{~min}$ at $50^{\circ} \mathrm{C}$ (water bath), $2.5 \mathrm{~mL}$ of trichloroacetic acid (10\%) was added to the mixture. Then, the solution was centrifuged at $3000 \mathrm{Trs} /$ min for $10 \mathrm{~min}$. Finally, $2.5 \mathrm{~mL}$ of the supernatant was mixed with $2.5 \mathrm{~mL}$ of distilled water and $0.5 \mathrm{~mL}$ of $0.1 \%$ ferric chloride. Absorbance was measured at $700 \mathrm{~nm}$.

Ascorbic acid $(50-450 \mu \mathrm{g} / \mathrm{mL})$ is used as a standard. The reducing power is expressed in milligram equivalence of ascorbic acid per gram of essential oil (mg AAE/g of EO). 


\subsection{Antimicrobial Activity}

2.4.1. Microorganism Strains, Origin, and Growth Conditions. The foodborne pathogenic bacteria used including Gram-positive (Listeria innocua CECT 4030, Staphylococcus aureus CECT 976, and Bacillus subtilis DSM 6633) and Gram-negative (Proteus mirabilis, Escherichia coli K12, and Pseudomonas aeruginosa CECT 118) bacteria were obtained from the Laboratory of Biology and Health, Sciences Faculty of Tetouan; Candida albicans ATCC 10231 was, also, used which was obtained from the Laboratory of Agri-Food and Health, Sciences and Technics Faculty of Settat, Morocco. Plant pathogenic bacteria were Clavibacter michiganensis subsp. michiganensis 1616-3 and Pseudomonas savastanoi pv. savastanoi (PSS2636-40) which were obtained from the Laboratory of Researches and Protection of Plants, URPP- INRA-Meknes, Morocco.

The pathogen bacterial strains were cultivated in Mueller-Hinton agar (MHA) or Mueller-Hinton Broth (MHB) at $37^{\circ} \mathrm{C}$ for $24 \mathrm{~h}$ as described by Benali et al. [52]. The fungi and the phytopathogenic bacteria were cultured in YPGA medium ( $5 \mathrm{~g}$ yeast extract, $5 \mathrm{~g}$ peptone, $10 \mathrm{~g}$ glucose, 15-18 $\mathrm{g}$ agar, in 1 liter) or YPG and incubated as following: $48 \mathrm{~h}$ at $37^{\circ} \mathrm{C}$ for Candida albicans ATCC $10231 ; 48 \mathrm{~h}$ at $25^{\circ} \mathrm{C}$ for Pseudomonas savastanoi pv. savastanoi $636-40 ; 72 \mathrm{~h}$ at $25^{\circ} \mathrm{C}$ for Clavibacter michiganensis subsp. michiganensis 1616-3. The inoculum test concentrations are $10^{6} \mathrm{CFU} / \mathrm{mL}$ for bacteria, $10^{8} \mathrm{CFU} / \mathrm{mL}$ for phytopathogenic plant, and $10^{5}$ spores/mL for fungi.

2.4.2. Antimicrobial Activity. The antibacterial activity was evaluating using disc diffusion method as described by Benali et al. [52] and Rota et al. [55], with some modifications. In brief, sterile disks (6 mm diameter) containing $12.5 \mu \mathrm{L}$ of pure essential oil were applied onto the surface of the agar medium which were previously spread by the test inoculum concentrations. Gentamicin $(15 \mu \mathrm{g})$, vancomycin $(30 \mu \mathrm{g})$, streptomycin $(25 \mu \mathrm{g})$, and amphotericin $(10 \mu \mathrm{g})$ were used as a positive control. Negative control consisted of $10 \%$ dimethylsulfoxide (DMSO). After incubation as described above, the antimicrobial activity was assessed by measuring the diameter of inhibition zones. Tests were performed in triplicate.

2.4.3. Determination of Minimum Inhibitory Concentration. MIC was determined only for strains considered very sensitive and essential oils considered very active leading to diameters larger than $15 \mathrm{~mm}$ [52-56]. Minimum inhibitory concentrations (MICs) were realized in sterile 96-well microplate as described by Güllüce et al. [22], with some modifications. First, $100 \mu \mathrm{L}$ of $\mathrm{MHB}$ was distributed in all test wells, except the first well in which a volume of $200 \mu \mathrm{L}$ containing the essential oil at a concentration of $25 \mathrm{mg} / \mathrm{mL}$ in $10 \%$ DMSO. A series of concentrations ranging from 0.097 to $25 \mathrm{mg} / \mathrm{mL}$ were prepared by the transfer of $100 \mu \mathrm{L}$ by scalar dilutions from the first to the ninth well. Then, except the 10th well used as sterility control, $10 \mu \mathrm{L}$ of the suspension from each well was removed and replaced by the test inoculum concentrations as described above. The eleventh well was considered as positive growth control containing only broth medium. The last well containing $10 \%$ DMSO (v/v), without oils, was used as negative control. Then, the plates were incubated at conditions of growth as described above. After incubation, a volume of $25 \mu \mathrm{L}$ of an indicator of microorganism's growth was added in each well, and tetrazolium (MTT: 3-(4,5-dimethythiazol)-2-yl-2, 5diphenyltetrazolium bromide (Sigma)) was prepared at a concentration of $0.5 \mathrm{mg} / \mathrm{mL}$ in sterile distilled water. The microplate was re-incubated for $30 \mathrm{~min}$ at temperature $25^{\circ} \mathrm{C}$ or $37^{\circ} \mathrm{C}$. Where microbial growth was inhibited, the solution keeps the initial color of MTT. To determine the minimum bactericidal concentration (MBC) value, $10 \mu \mathrm{L}$ of broth from the uncolored wells was inoculated and incubated at growth conditions.

2.5. Statistical Analysis. All experiments were done in triplicates and values of each were expressed as mean\pm standard deviation (SD) and were subjected to analysis of variance (one-way ANOVA). The statistical analysis was performed using GraphPad Prism version 6.00 (GraphPad Inc., San Diego, California). Differences (between groups) were considered as statistically significant at $p<0.05$.

\section{Results}

3.1. Chemical Composition. The essential oil yields (w/w) were $0.24 \pm 0.02 \%$ and $0.18 \pm 0.02 \%$, for Micromeria graeca and Teucrium polium subsp. polium, respectively. Volatile compounds of both studied plants were separated by GC (Figures 1 and 2) and identified using MS analysis. The results obtained by GC-MS analysis of EOs are summarized in Table 1. As summarized, 29 and 5 compounds were identified in TPpEO and MGEO representing 97.46\% and 99.95\% of the total, respectively. Our results showed that the major compounds in TPpEO are $\beta$-pinene (19.82\%), germacrene D (18.33\%), $\alpha$-cadinol (6.83\%), $\alpha$-pinene $(6.76 \%)$, limonene (5.71\%), epi-bicyclosesquiphellandrene (5.05\%), delta-cadinene $(4.51 \%)$, spathulenol (4.15\%), bicyclogermacrene $(3.21 \%)$, myrcene $(2.9 \%)$, and camphor $(2.45 \%)$. However, MGEO contains geranial (36.93\%) as a main component followed bay $z$-citral $(18.25 \%)$, 1,8-epoxy-pmenth-2-ene (13.01\%), nerol (11.96\%), and isoaromadendrene epoxide (10.14\%).

3.2. Antioxidant Activity. The essential oils were evaluated for their antioxidant effect using two methods, the DPPH free radical scavenging and the ferric ion reduction assay (FRAP). For the DPPH assay, as summarized in Table 2, the most potent activity was obtained from $M$. graeca $\left(\mathrm{IC}_{50}=189.7 \pm 2.62 \mu \mathrm{g} / \mathrm{mL}\right)$, followed by $T$. polium $\left(\mathrm{IC}_{50}=208.33 \pm 3.51 \mu \mathrm{g} / \mathrm{mL}\right)$, but they were all less potent than the standards used as positive controls, namely, Trolox and ascorbic acid $\left(\mathrm{IC}_{50}=1.4 \pm 0.04 \mu \mathrm{g} / \mathrm{mL}\right.$ and $\mathrm{IC}_{50}=1.82 \pm 0.025 \mu \mathrm{g} / \mathrm{mL}$, respectively). For the FRAP test, the results were expressed in milligram equivalence of ascorbic acid per gram of extract (mg AAE/g of EO), and the 


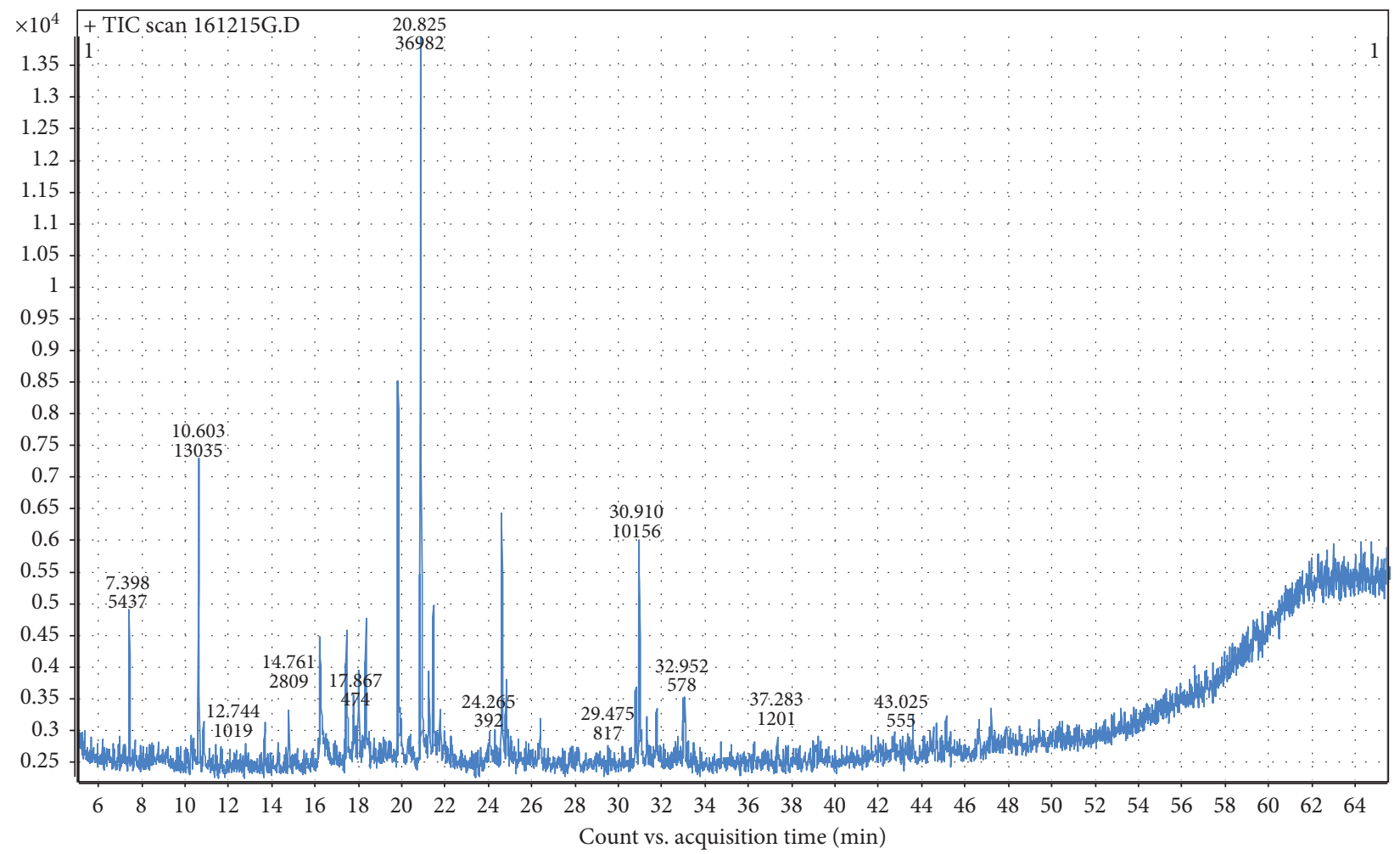

FIgURE 1: GC analysis of Micromeria graeca essential oil.

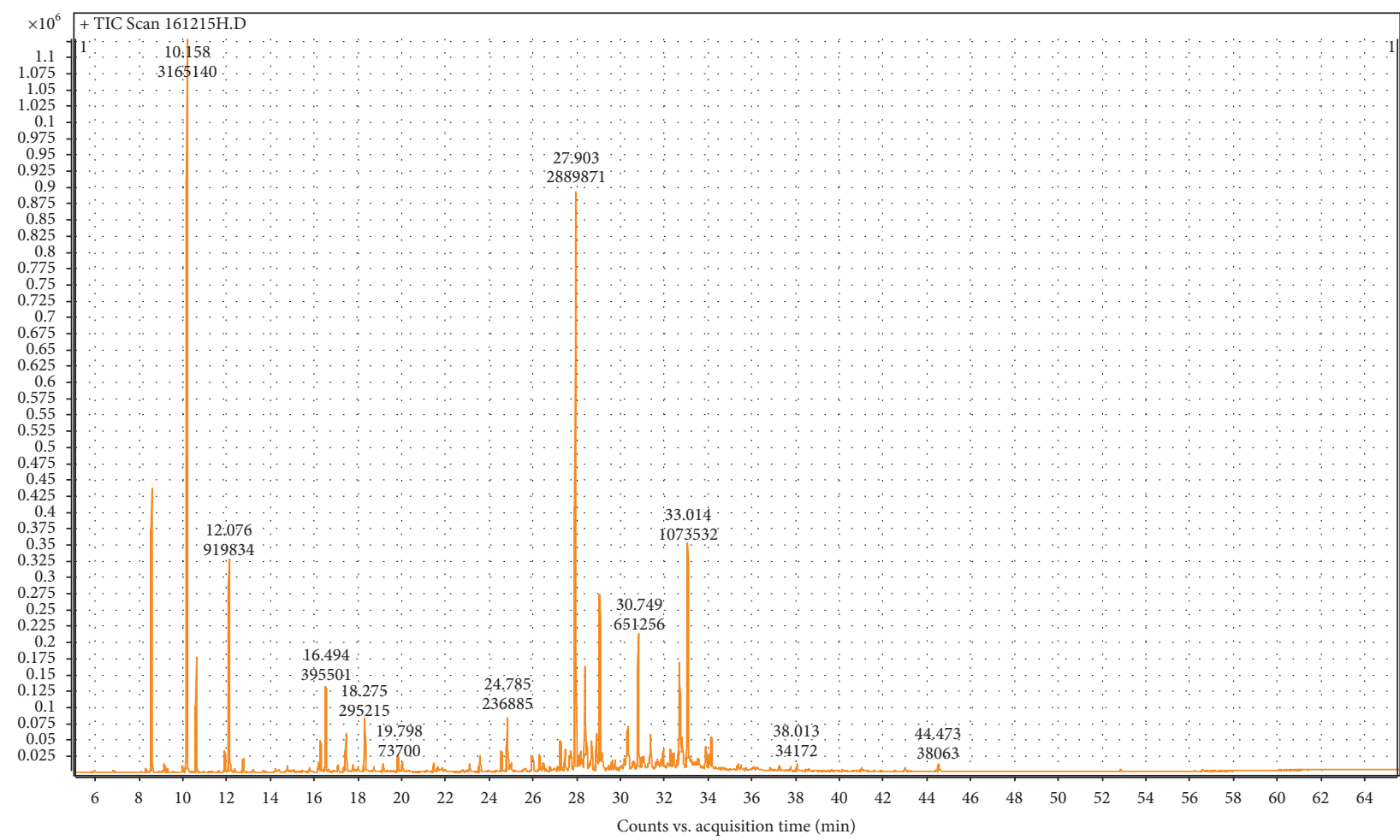

FIgUre 2: GC analysis of Teucrium polium subsp. polium essential oil. 
TABle 1: Chemical composition of essential oils of Teucrium polium subsp. polium and Micromeria graeca from Northern Morocco.

\begin{tabular}{|c|c|c|c|}
\hline \multirow{2}{*}{ Compounds } & \multirow{2}{*}{${ }^{*} \mathrm{IR}$} & Teucrium polium subsp. polium & Micromeria graeca \\
\hline & & \multicolumn{2}{|c|}{ Concentration (\% peak area) } \\
\hline Unknown & - & - & 5.43 \\
\hline$\alpha$-Pinene & 930 & 6.76 & - \\
\hline$\beta$-Pinene & 975 & 19.82 & - \\
\hline Myrcene & 987 & 2.9 & - \\
\hline 1,8-Epoxyl-p-menth-2-ene & 988 & - & 13.01 \\
\hline p-Cymene & 1025 & 0.55 & - \\
\hline Limonene & 1031 & 5.71 & - \\
\hline Unknown & 1108 & - & 2.8 \\
\hline trans-Pinocarveol & 1145 & 0.89 & - \\
\hline Camphor & 1151 & 2.45 & - \\
\hline Borneol & 1174 & 1.1 & - \\
\hline Unknown & 1184 & - & 0.47 \\
\hline 2-Methyl-1-nonene-3-yne & 1194 & 1.83 & - \\
\hline$z$-Citral & 1237 & - & 18.25 \\
\hline Geranial & 1266 & - & 36.93 \\
\hline Unknown & 1367 & - & 0.39 \\
\hline$\alpha$-Copaene & 1375 & 0.59 & - \\
\hline Nerol & 1376 & - & 11.96 \\
\hline$\beta$-Bourbonene & 1382 & 1.45 & - \\
\hline Alloaromadendrene & 1559 & 1.02 & - \\
\hline (E),z-3-Ethylidenecyclohexane & 1465 & 0.71 & - \\
\hline Germacrene D & 1481 & 18.33 & - \\
\hline$\beta$-Selinene & 1488 & 0.66 & - \\
\hline Bicyclogermacrene & 1495 & 3.21 & - \\
\hline$\alpha$-Muurolene & 1497 & 0.83 & - \\
\hline$\alpha$-Gurjunene & 1504 & 1.13 & - \\
\hline$\gamma$-Cadinene & 1512 & 1.04 & - \\
\hline$\delta$-Cadinene & 1517 & 4.51 & - \\
\hline (e)-Farnesene & 1560 & 1.93 & - \\
\hline Spathulenol & 1576 & 4.15 & - \\
\hline Isoaromadendrene epoxide & 1581 & - & 10.14 \\
\hline 2-Allyphenol & 1615 & 0.68 & - \\
\hline Cadina-1,4-diene & 1626 & 0.56 & - \\
\hline epi-Bicyclosesquiphellandrene & 1641 & 5.05 & - \\
\hline$(-)$-Isoledene & 1645 & 1.02 & - \\
\hline Unknown & 1652 & - & 0.57 \\
\hline$\alpha$-Cadinol & 1655 & 6.83 & - \\
\hline Italicene & 1684 & 0.76 & - \\
\hline$\alpha$-Elemene & 1692 & 0.99 & - \\
\hline Total: & & 97.46 & 90.26 \\
\hline
\end{tabular}

${ }^{*} \mathrm{IR}=$ retention indices relative to $\mathrm{C}_{9}-\mathrm{C}_{31} \mathrm{n}$-alkanes on the DB-5MS capillary column.

Table 2: Antioxidant activities of Teucrium polium ssp. polium and Micromeria graeca essential oils.

\begin{tabular}{|c|c|c|c|c|}
\hline \multirow{2}{*}{ Assays } & \multicolumn{2}{|c|}{ Essential oils } & \multirow{2}{*}{ Ascorbic acid } & \multirow{2}{*}{ Trolox } \\
\hline & T. polium subsp. polium & M. graeca & & \\
\hline $\mathrm{DPPH}\left(\mathrm{IC}_{50}, \mu \mathrm{g} / \mathrm{mL}\right)$ & $208.33 \pm 3.51$ & $189.7 \pm 2.62$ & $1.82 \pm 0.025$ & $1.40 \pm 0.04$ \\
\hline Reducing power (mg AAE/g of EO)* & $1.32 \pm 0.10$ & $0.51 \pm 0.13$ & nt & $\mathrm{nt}$ \\
\hline
\end{tabular}

${ }^{*} \mathrm{mg}$ AAE/g EO: milligram equivalence of ascorbic acid per gram of essential oil. Values represent mean (standard deviations) for triplicate experiments. nt: not tested.

highest reducing power was obtained from TPpEO $1.32 \pm 0.1 \mathrm{mg} \mathrm{AAE} / \mathrm{g}$ of EO compared to MGEO $0.51 \pm 0.13 \mathrm{mg} \mathrm{AAE} / \mathrm{g}$ of $\mathrm{EO}$.

3.3. Antimicrobial Activity. The in vitro antimicrobial activity of the essential oils against the tested microorganisms was qualitatively and quantitatively confirmed by diameter of inhibition zone and the MIC values. As shown in Tables 3 and 4, the essential oils exhibited varying degrees of antibacterial activity against all tested strains. For the essential oil of TPpEO, the inhibition zones were in the range from 7.33 to $52 \mathrm{~mm}$, with MIC values of $0.19 \mathrm{mg} / \mathrm{mL}$ and $0.78 \mathrm{mg} / \mathrm{mL}$. C. michiganensis was the most sensitive bacteria to TPpEO with inhibition 
TAвLe 3: Antimicrobial activity of T. polium subsp. polium and M. graeca essential oils using disc diffusion method.

\begin{tabular}{|c|c|c|c|c|c|c|}
\hline & \multicolumn{6}{|c|}{ Inhibition zones diameter $(\mathrm{mm})^{*}$} \\
\hline & \multicolumn{3}{|c|}{ Essential oils } & \multicolumn{3}{|c|}{ Antimicrobial agents } \\
\hline & $\begin{array}{l}\text { T. polium subsp. } \\
\text { polium }\end{array}$ & M. graeca & $\begin{array}{l}\text { Gentamicin } \\
\quad(15 \mu \mathrm{g})\end{array}$ & $\begin{array}{l}\text { Vancomycin } \\
(30 \mu \mathrm{g})\end{array}$ & $\begin{array}{l}\text { Streptomycin } \\
25 \mu \mathrm{g}\end{array}$ & $\begin{array}{l}\text { Amphotericin } \\
(10 \mu \mathrm{g})\end{array}$ \\
\hline S. aureus CECT 976 & $9.66 \pm 1.52^{+}$ & $22 \pm 1^{+++}$ & $34.33 \pm 0.57$ & $30.66 \pm 0.57$ & $\mathrm{nt}$ & nt \\
\hline B. subtilis DSM 6633 & $23 \pm 2^{+++}$ & $28.33 \pm 1.52^{+++}$ & $26 \pm 1$ & $27.66 \pm 0.57$ & $\mathrm{nt}$ & nt \\
\hline L. innocua CECT 4030 & $11.33 \pm 1.52^{+}$ & $19.33 \pm 1.15^{++}$ & $17.66 \pm 0.57$ & $25.33 \pm 0.57$ & nt & nt \\
\hline E. coli $\mathrm{K} 12$ & $10.33 \pm 1.52^{+}$ & $17.66 \pm 1.52^{++}$ & $20.33 \pm 0.5$ & $8 \pm 00$ & $\mathrm{nt}$ & nt \\
\hline $\begin{array}{l}\text { P. aeruginosa CECT } \\
118\end{array}$ & $9.33 \pm 0.57^{+}$ & $9.33 \pm 1.52^{+}$ & $19 \pm 1$ & n.e & nt & nt \\
\hline P. mirabilis & $21.33 \pm 2.08^{+++}$ & $20 \pm 2^{+++}$ & $28.66 \pm 0.57$ & $24.33 \pm 0.57$ & $\mathrm{nt}$ & nt \\
\hline $\begin{array}{l}\text { C. michiganensis 1616- } \\
3\end{array}$ & $52 \pm 1^{+++}$ & $>65$ & nt & nt & $24.66 \pm 0.57$ & nt \\
\hline $\begin{array}{l}\text { P. savastanoi } \\
\text { PSS2636-40) }\end{array}$ & $22 \pm 1^{+++}$ & $49 \pm 1^{+++}$ & nt & nt & $26.33 \pm 0.57$ & nt \\
\hline $\begin{array}{l}\text { C. albicans ATCC } \\
10231\end{array}$ & $7.33 \pm 0.57^{-}$ & $44.33 \pm 0.57^{+++}$ & nt & nt & $\mathrm{nt}$ & $18.66 \pm 1.15$ \\
\hline
\end{tabular}

*The diameter of the inhibition zones $(\mathrm{mm})$, including diameter of disc $(6 \mathrm{~mm})$, is given as mean \pm SD of triplicate experiments. nt: not tested; n.e: no effect. The sensitivity to the different oils was classified by the diameter of the inhibition halos as follows: not sensitive (-) for diameters less than $8 \mathrm{~mm}$; sensitive ( + ) for diameters 9-14 mm; very sensitive (++) for diameters $15-19 \mathrm{~mm}$; and extremely sensitive $(+++)$ for diameters larger than $20 \mathrm{~mm}$.

TABLE 4: Minimum inhibitory concentration (MIC) and minimum bactericidal (MBC) or fungicidal (MFC) concentrations $\mathrm{mg} / \mathrm{ml}$ of essential oils.

\begin{tabular}{lcccc}
\hline & \multicolumn{4}{c}{ Essential oils } \\
Tested microbial strains & $\begin{array}{c}\text { Teucrium polium } \\
\text { subsp. polium } \\
\text { MBC or }\end{array}$ & Micromeria graeca \\
& MIC & MFC & MIC & MBC or \\
MFC
\end{tabular}

zone of $52 \pm 1 \mathrm{~mm}$ with MIC value of $0.78 \mathrm{mg} / \mathrm{mL}$, followed by B. subtilis $(23 \pm 2 \mathrm{~mm}), P$. savastanoi PSS2636$40(22 \pm 1 \mathrm{~mm})$, and $P$. mirabilis $(21.33 \pm 2.08 \mathrm{~mm})$. This oil has a low effect against the other bacteria. No antifungal activity is observed against $C$. albicans $(7.33 \pm 0.57 \mathrm{~mm})$.

For MGEO, the inhibition zones varied from 9.33 to $>65 \mathrm{~mm}$, with MIC values from 0.19 to $12.5 \mathrm{mg} / \mathrm{mL}$. C. michiganensis was the most sensitive bacteria with inhibition zone superior to $65 \mathrm{~mm}$ with MIC value of $0.19 \mathrm{mg} / \mathrm{mL}$, followed by $P$. savastanoi PSS2636-40 $(49 \pm 1 \mathrm{~mm}), \quad B$. subtilis $(28.33 \pm 1.52 \mathrm{~mm}), \quad S$. aureus $(22 \pm 1 \mathrm{~mm}), \quad P$. mirabilis $(20 \pm 2 \mathrm{~mm}), \quad$ L. innocua $(19.33 \pm 1.15 \mathrm{~mm})$, and E. coli $K 12(17.66 \pm 1.52 \mathrm{~mm})$. For antifungal activity, MGEO exhibits a good anticandidal effect with an inhibition zone of $44.33 \pm 0.57 \mathrm{~mm}$ and MIC value of $3.12 \mathrm{mg} / \mathrm{mL}$ compared to control positive amphotericin $(18.66 \pm 1.15 \mathrm{~mm})$.

\section{Discussion}

TPpEO and MGEO aerial parts showed qualitative and/or quantitative variability in chemical composition when compared with other reports. The GC-MS analysis of TPpEO and MGEO aerial parts showed that the present finding is similar to those of Algerian T. polium subsp. polium that demonstrated germacrene (14.8\%) $\beta$-pinene (16.6\%), and $\alpha$-pinene (7.2\%) as main compounds [57], except for $\alpha$-cadinol (6.83\%), epi-bicyclosesquiphellandrene (5.05\%), $\delta$-cadinene $(4.51 \%)$, and camphor $(2.45 \%)$, which were not detected in the Algerian sample. However, the results are different to the only one investigation of oil analysis of Moroccan T. polium subsp. polium from the regions of Midelt, which indicated 3-carene (16.49\%), $\gamma$-muurolene $(14.03 \%), \alpha$-pinene $(9.94 \%), \alpha$-phellandrene (6.93\%), and caryophyllene $(7.51 \%)$ as major constituents [58]. The results of the volatile product analysis of Teucrium polium species from Saudi Arabia, Algeria, Jordan, Greece, Turkey, and Serbia identified the following compounds with a high content: $\beta$-pinene, limonene, germacrene $\mathrm{D}, \alpha$-pinene, bicyclogermacrene, and spathulenol [59-64].

For MGEO from Morocco, this is the first study of their chemical composition. In Greece, EOs of two samples of this plant were characterized by the presence of caryophyllene oxide (17.0\%), epi- $\alpha$-bisabolol (12.8\%), linalool (18.1\%), and $\beta$-chamigrene (12.5\%) [65]. Compared with other species of the Micromeria genus, the study of the chemical composition of Micromeria cilicica EO from Tukey showed that the major components characterized were pulegone, cis-p-menthone, and trans-p-menthone [66]. In addition, Micromeria fruticosa oil was characterized by a high content of $\gamma$-terpinene, $\beta$-caryophyllene, $\mathrm{p}$-cymene, $\alpha$-pinene, and $\beta$-bisabolene [67]. These results indicated the possibility of the chemical composition difference in Micromeria EOs from one species to another. The qualitative and/or quantitative difference between the oil composition in our results and those noticed in 
previous works may be attributed to the ecological factors, genetic differences, environment, geographical origins, and season of harvest [68-72].

As indicated above, $\beta$-pinene, germacrene $\mathrm{D}$, and $\alpha$-pinene were among the major compounds of TPpEO chemical composition and nerol and $z$-citral were for MGEO. Previous research studies showed the antioxidant effect of $\beta$-pinene, germacrene $\mathrm{D}$, and $\alpha$-pinene tested individually [73-77]. Also, nerol and citral are known for their antioxidant efficacy [78-80]. These proprieties can explain the antioxidant activity of both essential oils. The small difference of antioxidant activity between TPpEO and MGEO may be associated to the variability in chemical composition since the antioxidant mechanisms of essential oils are generally caused by several compounds' functional groups and their structure [81]. However, the difference observed between testing methods could be explained by the correlation between the chemical composition and/or each compound and the used method [82-84].

For the antibacterial activity, it is known that the Gramnegative bacteria are less sensitive to plant extracts than Gram-positive ones [85-87]. However, the present findings showed that essential oils of plants studied do not have selective antibacterial effects against microorganisms tested. This result may be related to the high level of $\beta$-pinene, germacrene $\mathrm{D}$, and $\alpha$-pinene (TPpEO) and $\mathrm{z}$-citral and nerol (MGEO). Antibacterial and antifungal activities of these substances have been reported in other studies [75, 88-96]. On the other hand, previous research studies reported the synergic effect of minor compounds against bacteria [97, 98].

\section{Conclusion}

To the best of our knowledge, this is the first report contributing details on chemical composition and antioxidant and antimicrobial activities of Teucrium polium subsp. polium and Micromeria graeca essential oils from Northern Morocco. Our findings have shown that both essential oils are rich by volatile compounds which could be responsible for the observed antibacterial and antioxidant effects. TPpEO and MGEO may be proposed as natural antioxidant and antibacterial product for application on food preservation and management against phytopathogenic bacteria. Further in vivo studies will be recommended to investigate their biological proprieties and negative effects before the practical applications.

\section{Data Availability}

The data used in this study are included within the article.

\section{Conflicts of Interest}

The authors declare that they have no conflicts of interest.

\section{Acknowledgments}

We are very thankful to the Laboratory of Biology and Health, Sciences Faculty of Tetouan, the Laboratory of AgriFood and Health of FST-Settat, and the Laboratory of
Research and Protection of Plants, URPP- INRA-Meknes, Morocco, for providing us with the microorganisms used in this study. We also acknowledge Prof. Ennabili Abdeslam for the identification of Micromeria graeca.

\section{References}

[1] A. A. Catherine, H. Deepika, and P. S. Negi, "Antibacterial activity of eugenol and peppermint oil in model food systems," Journal of Essential Oil Research, vol. 24, no. 5, pp. 481-486, 2012.

[2] R. Kotan, A. Çakir, H. Ozer et al., "Antibacterial effects of Origanum onites against phytopathogenic bacteria: possible use of the extracts from protection of disease caused by some phytopathogenic bacteria," Scientia Horticulturae, vol. 172, pp. 210-220, 2014.

[3] M. B. Isman, "Plant essential oils for pest and disease management," Crop Protection, vol. 19, no. 8-10, pp. 603-608, 2000.

[4] G. M. Balestra, A. Heydari, D. Ceccarelli, E. Ovidi, and A. Quattrucci, "Antibacterial effect of Allium sativum and Ficuscarica extracts on tomato bacterial pathogens," Crop Protection, vol. 28, no. 10, pp. 807-811, 2009.

[5] M. Friedman, P. R. Henika, and R. E. Mandrell, "Bactericidal activities of plant essential oils and some of their isolated constituents against Campylobacter jejuni, Escherichia coli, Listeria monocytogenes, and Salmonella enterica," Journal of Food Protection, vol. 65, no. 10, pp. 1545-1560, 2002.

[6] S. Burt, "Essential oils: their antibacterial properties and potential applications in foods-a review," International Journal of Food Microbiology, vol. 94, no. 3, pp. 223-253, 2004.

[7] S. Chanthaphon, S. Chanthachum, and T. Hongpattarakere, "Antimicrobial activities of essential oils and crude extracts from tropical Citrus spp. against food-related microorganisms," Songklanakarin Journal of Science and Technology, vol. 30, no. 1, pp. 125-131, 2008.

[8] L. Manniche, Sacred Luxuries: Fragrance, Aromatherapy and Cosmetics in Ancient Egypt, Cornell University Press, New York, NY, USA, 1999.

[9] A. Krishna, R. Tiwari, and S. Kumar, "Aromatherapy-an alternative health care through essential oils," Journal of $\mathrm{Me}$ dicinal and Aromatic Plant Sciences, vol. 22, no. 1, pp. 798-804, 2000.

[10] P. Lai and J. Roy, "Antimicrobial and chemopreventive properties of herbs and spices," Current Medicinal Chemistry, vol. 11, no. 11, pp. 1451-1460, 2004.

[11] A. Rahman, Z. Sultana Shanta, M. A. Rashid et al., "In vitro antibacterial properties of essential oil and organic extracts of Premna integrifolia Linn," Arabian Journal of Chemistry, vol. 9, no. 1, pp. S475-S479, 2016.

[12] A. I. Hussain, F. Anwar, P. S. Nigam et al., "Antibacterial activity of some Lamiaceae essential oils using resazurin as an indicator of cell growth," LWT-Food Science and Technology, vol. 44, no. 4, pp. 1199-1206, 2011.

[13] S. Ćavar, M. Maksimović, D. Vidic, and A. Parić, "Chemical composition and antioxidant and antimicrobial activity of essential oil of Artemisia annua L. from Bosnia," Industrial Crops and Products, vol. 37, no. 1, pp. 479-485, 2012.

[14] J. M. Alves-Silva, S. M. Dias dos Santos, M. E. Pintado, J. A. Pérez-Álvarez, J. Fernández-López, and M. ViudaMartos, "Chemical composition and in vitro antimicrobial, antifungal and antioxidant properties of essential oils obtained from some herbs widely used in Portugal," Food Control, vol. 32, no. 2, pp. 371-378, 2013. 
[15] Z. B. O. S. Said, H. Haddadi-Guemghar, L. BoulekbacheMakhlouf et al., "Essential oils composition, antibacterial and antioxidant activities of hydrodistillated extract of Eucalyptus globulus fruits," Industrial Crops and Products, vol. 89, pp. 167-175, 2016.

[16] I. Bajalan, R. Rouzbahani, A. G. Pirbalouti, and F. Maggi, "Antioxidant and antibacterial activities of the essential oils obtained from seven Iranian populations of Rosmarinus officinalis," Industrial Crops and Products, vol. 107, pp. 305-311, 2017.

[17] H. Xiang, L. Zhang, Z. Yang, F. Chen, X. Zheng, and X. Liu, "Chemical compositions, antioxidative, antimicrobial, antiinflammatory and antitumor activities of Curcuma aromatica Salisb. essential oils," Industrial Crops and Products, vol. 108, pp. 6-16, 2017.

[18] S. Siddique, Z. Parveen, F. e-Bareen, and S. Mazhar, "Chemical composition, antibacterial and antioxidant activities of essential oils from leaves of three Melaleuca species of Pakistani flora," Arabian Journal of Chemistry, vol. 13, no. 1, pp. 67-74, 2017.

[19] S. Pattnaik, V. R. Subramanyam, M. Bapaji, and C. R. Kole, "Antibacterial and antifungal activity of aromatic constituents of essentials oils," Microbios, vol. 8, no. 358, pp. 39-46, 1997.

[20] J. M. Wilkinson, M. Hipwell, T. Ryan, and H. M. A. Cavanagh, "Bioactivity ofBackhousia citriodora: antibacterial and antifungal activity," Journal of Agricultural and Food Chemistry, vol. 51, no. 1, pp. 76-81, 2003.

[21] S. Kordali, R. Kotan, A. Mavi, A. Cakir, A. Ala, and A. Yildirim, "Determination of the chemical composition and antioxidant activity of the essential oil ofArtemisia dracunculusand of the antifungal and antibacterial activities of TurkishArtemisiaabsinthium,A. dracunculus,Artemisia santonicum, andArtemisia spicigeraEssential oils," Journal of Agricultural and Food Chemistry, vol. 53, no. 24, pp. 94529458, 2005.

[22] M. Güllüce, F. Sahin, M. Sokmen et al., "Antimicrobial and antioxidant properties of the essential oils and methanol extract from Mentha longifolia L. ssp. longifolia," Food Chemistry, vol. 103, no. 4, pp. 1449-1456, 2007.

[23] J. S. Dambolena, M. P. Zunino, A. G. López et al., "Essential oils composition of Ocimum basilicum L. and Ocimum gratissimum L. from Kenya and their inhibitory effects on growth and fumonisin production by Fusarium verticillioides," Innovative Food Science \& Emerging Technologies, vol. 11, no. 2, pp. 410-414, 2010.

[24] M. Nikolić, K. K. Jovanović, T. Marković et al., "Chemical composition, antimicrobial, and cytotoxic properties of five Lamiaceae essential oils," Industrial Crops and Products, vol. 61, pp. 225-232, 2014.

[25] A. Piras, M. J. Gonçalves, J. Alves et al., “Ocimum tenuiflorum L. and Ocimum basilicum L., two spices of Lamiaceae family with bioactive essential oils," Industrial Crops and Products, vol. 113, pp. 89-97, 2018.

[26] F. Bakkali, S. Averbeck, D. Averbeck, and M. Idaomar, "Biological effects of essential oils-a review," Food and Chemical Toxicology, vol. 46, no. 2, pp. 446-475, 2008.

[27] B. Ben Slimane, O. Ezzine, S. Dhahri, H. Chograni, and M. L. Ben Jamaa, "Chemical composition of Rosmarinus and Lavandula essential oils and their insecticidal effects on Orgyiatrigotephras(Lepidoptera, Lymantriidae)," Asian Pacific Journal of Tropical Biomedicine, vol. 2, pp. 98-103, 2015.

[28] M. Christofoli, E. C. C. Costa, K. U. Bicalho et al., "Insecticidal effect of nanoencapsulated essential oils from Zanthoxylum rhoifolium (Rutaceae) in Bemisia tabaci populations," Industrial Crops and Products, vol. 70, pp. 301-308, 2015.

[29] G. E. Nenaah, S. I. A. Ibrahim, and B. A. Al-Assiuty, "Chemical composition, insecticidal activity and persistence of three Asteraceae essential oils and their nanoemulsions against Callosobruchus maculatus (F.)," Journal of Stored Products Research, vol. 61, pp. 9-16, 2015.

[30] C. A. Filomeno, L. C. A. Barbosa, R. R. Teixeira et al., "Corymbia spp. and Eucalyptus spp. essential oils have insecticidal activity against Plutella xylostella," Industrial Crops and Products, vol. 109, pp. 374-383, 2017.

[31] M. Chellappandian, P. Vasantha-Srinivasan, S. Senthil-Nathan et al., "Botanical essential oils and uses as mosquitocides and repellents against dengue," Environment International, vol. 113, pp. 214-230, 2018.

[32] A. Russo, C. Formisano, D. Rigano et al., "Chemical composition and anticancer activity of essential oils of Mediterranean sage (Salvia officinalis L.) grown in different environmental conditions," Food and Chemical Toxicology, vol. 55, pp. 42-47, 2013.

[33] M. Asif, A. H. S. Yehya, M. A. Al-Mansoub et al., "Anticancer attributes of Illicium verum essential oils against colon cancer," South African Journal of Botany, vol. 103, pp. 156-161, 2016.

[34] L. Pudziuvelyte, M. Stankevicius, A. Maruska et al., "Chemical composition and anticancer activity of Elsholtzia ciliata essential oils and extracts prepared by different methods," Industrial Crops and Products, vol. 107, pp. 90-96, 2017.

[35] J. Bellakhdar, La pharmacopée marocaine traditionnelle. Médecine arabe ancienne et savoirs populaires, Ibis Press, Paris, France, 1997.

[36] Z. BenrahmouneIdrissi and C. Dubruille, Invitation à l'amour des plantes. Guide floristique illustré de la réserve biologique de Sidi Boughaba. Scriptura Editions, pp. 18-25, Imprimerie Al maarif al Jadida, Rabat, Morocco, 2003.

[37] H. Fougrach, W. Badri, and M. Malki, Flore vasculaire rare et menacée du massif de Tazekka (région de Taza, Maroc), Bulletin de l'Institut Scientifique, Bordeaux, France, 2007.

[38] A. Ennabili, N. Gharnit, and E. El hamdouni, "Inventory and social interest of medicinal, aromatic and honey-plants from mokrisset region (Nw of Morocco)," Medicinal plants, vol. 19, pp. 39-56, 2000.

[39] J. El-Hilaly, M. Hmammouchi, and B. Lyoussi, "Ethnobotanical studies and economic evaluation of medicinal plants in Taounate province (Northern Morocco)," Journal Ethnopharmacology, vol. 86, no. 2-3, pp. 149-158, 2003.

[40] A. Khabbach, M. Libiad, A. Ennabili, and D. Bousta, "Medicinal and cosmetic use of plants from the province of Taza, Northern Morocco," Boletin latinoamericano y del caribe de plantas medicinales y aromaticas, vol. 11, no. 1, pp. 46-60, 2012.

[41] A. Bouyahya, J. Abrini, A. Et-Touys, Y. Bakri, and N. Dakka, "Indigenous knowledge of the use of medicinal plants in the North-West of Morocco and their biological activities," European Journal of Integrative Medicine, vol. 13, pp. 9-25, 2017.

[42] P. Costa, B. Medronho, S. Gonçalves, and A. Romano, "Cyclodextrins enhance the antioxidant activity of essential oils from three Lamiaceae species," Industrial Crops and Products, vol. 70, pp. 341-346, 2015.

[43] M. H. Novais, I. Santos, S. Mendes, and C. Pinto-Gomes, "Studies on pharmaceutical ethnobotany in arrabida natural park (Portugal)," Journal of Ethnopharmacology, vol. 93, no. 2-3, pp. 183-195, 2004. 
[44] T. Benali, A. Khabbach, A. Ennabili, and K. Hammani, "Ethnopharmacological prospecting of medicinal plants from the Province of Guercif (NE of Morocco)," Moroccan Journal of Biology, vol. 14, pp. 1-14, 2017.

[45] A. Ait-Ouazzou, S. Lorán, M. Bakkali et al., "Chemical composition and antimicrobial activity of essential oils of Thymus algeriensis, Eucalyptus globulus and Rosmarinus officinalis from Morocco," Journal of the Science of Food and Agriculture, vol. 91, no. 14, pp. 2643-2651, 2011.

[46] A. Ait-Ouazzou, S. Lorán, A. Arakrak et al., "Evaluation of the chemical composition and antimicrobial activity of Mentha pulegium, Juniperus phoenicea, and Cyperus longus essential oils from Morocco," Food Research International, vol. 45, no. 1, pp. 313-319, 2012.

[47] L. El Bouzidi, C. A. Jamali, K. Bekkouche et al., "Chemical composition, antioxidant and antimicrobial activities of essential oils obtained from wild and cultivated Moroccan Thymus species," Industrial Crops and Products, vol. 43, pp. 450-456, 2013.

[48] A. Bouyahya, A. Et-Touys, Y. Bakri et al., "Chemical composition of Mentha pulegium and Rosmarinus officinalis essential oils and their antileishmanial, antibacterial and antioxidant activities," Microbial Pathogenesis, vol. 111, pp. 41-49, 2017.

[49] Y. Laghmouchi, O. Belmehdi, N. S. Senhaji, and J. Abrini, "Chemical composition and antibacterial activity of Origanum compactum Benth. essential oils from different areas at northern Morocco," South African Journal of Botany, vol. 115, pp. 120-125, 2018.

[50] A. El-Gharbaoui, G. Benítez, M. R. González-Tejero, J. Molero-Mesa, and A. Merzouki, "Comparison of Lamiaceae medicinal uses in eastern Morocco and eastern Andalusia and in Ibn al-Baytar's Compendium of Simple Medicaments (13th century CE)," Journal of Ethnopharmacology, vol. 202, pp. 208-224, 2017.

[51] T. Benali, A. Bouyahya, K. Habbadi, G. Zengin, A. Khabbach, and K. Hammani, "Chemical composition and antibacterial activity of the essential oil and extracts of Cistus ladaniferus subsp. ladanifer and Mentha suaveolens against phytopathogenic bacteria and their ecofriendly management of phytopathogenic bacteria," Biocatalysis and Agricultural Biotechnology, vol. 28, Article ID 101696, 2020.

[52] T. Benali, H. Chtibi, A. Bouyahya, A. Khabbach, and K. Hammani, "Detection of antioxidant and antimicrobial activities in phenol components and essential oils of cistus ladaniferus and mentha suaveolens extracts," Biomedical and Pharmacology Journal, vol. 13, no. 2, pp. 603-612, 2020.

[53] B. Huang, H. Ke, J. He, X. Ban, H. Zeng, and Y. Wang, "Extracts of Halenia elliptica exhibit antioxidant properties in vitro and in vivo," Food and Chemical Toxicology, vol. 49, no. 1, pp. 185-190, 2011.

[54] M. Oyaizu, "Studies on products of browning reaction. Antioxidative activities of products of browning reaction prepared from glucosamine," The Japanese Journal of $\mathrm{Nu}$ trition and Dietetics, vol. 44, no. 6, pp. 307-315, 1986.

[55] C. Rota, J. J. Carramiñana, J. Burillo, and A. Herrera, "In vitro antimicrobial activity of essential oils from aromatic plants against selected foodborne pathogens," Journal of Food Protection, vol. 67, no. 6, pp. 1252-1256, 2004.

[56] A. G. Ponce, R. Fritz, C. Del Valle, and S. I. Roura, “Antimicrobial activity of essential oils on the native microflora of organic Swiss chard," LWT-Food Science and Technology, vol. 36, no. 7, pp. 679-684, 2003.
[57] N. Djabou, A. Muselli, H. Allali et al., "Chemical and genetic diversity of two Mediterranean subspecies of Teucrium polium L." Phytochemistry, vol. 83, pp. 51-62, 2012.

[58] Y. El Atki, I. Aouam, F. El Kamari et al., "Phytochemistry, antioxidant and antibacterial activities of two Moroccan Teucrium polium L. subspecies: preventive approach against nosocomial infections," Arabian Journal of Chemistry, vol. 13, no. 2, pp. 3866-3874, 2020.

[59] M. M. A. Hassan, F. J. Muhtadi, and A. A. Al-Badr, "GLCmass spectrometry of Teucrium polium oil," Journal of Pharmaceutical Sciences, vol. 68, no. 6, pp. 800-801, 1979.

[60] A. Çakir, M. E. Duru, M. Harmandar, R. Ciriminna, and S. Passannanti, "Volatile constituents ofTeucrium poliumL. From Turkey," Journal of Essential Oil Research, vol. 10, no. 1, pp. 113-115, 1998.

[61] N. N. Kovacevic, B. S. Lakusic, and M. S. Ristic, "Composition of the essential oils of SevenTeucriumSpecies from Serbia and Montenegro," Journal of Essential Oil Research, vol. 13, no. 3, pp. 163-165, 2001.

[62] T. Aburjai, M. Hudaib, and V. Cavrini, "Composition of the essential oil from Jordanian germander (Teucrium poliumL.)," Journal of Essential Oil Research, vol. 18, no. 1, pp. 97-99, 2006.

[63] F. Menichini, F. Conforti, D. Rigano, C. Formisano, F. Piozzi, and F. Senatore, "Phytochemical composition, anti-inflammatory and antitumour activities of four Teucrium essential oils from Greece," Food Chemistry, vol. 115, no. 2, pp. 679-686, 2009.

[64] N. Fertout-Mouri, A. Latrèche, Z. Mehdadi, F. Toumi-Bénali, and M. B. Khaled, "Composition chimique et activité antibactérienne de l'huile essentielle de Teucrium polium L. du mont de Tessala (Algérie occidentale)," Phytothérapie, vol. 15, no. 6, pp. 346-353, 2017.

[65] O. Tzakou and M. Couladis, "The essential oil ofMicromeria graeca (L.) Bentham et Reichenb. growing in Greece," Flavour and Fragrance Journal, vol. 16, no. 2, pp. 107-109, 2001.

[66] M. E. Duru, M. Öztürk, A. Uğur, and Ö. Ceylan, "The constituents of essential oil and in vitro antimicrobial activity of Micromeria cilicica from Turkey," Journal of Ethnopharmacology, vol. 94, no. 1, pp. 43-48, 2004.

[67] C. Formisano, E. Mignola, D. Rigano et al., "Chemical composition and antimicrobial activity of the essential oil from aerial parts ofMicromeria fruticulosa (Bertol.) Grande (Lamiaceae) growing wild in Southern Italy," Flavour and Fragrance Journal, vol. 22, no. 4, pp. 289-292, 2007.

[68] Y. Holm, I. Laakso, R. Hiltunen, and B. Galambosi, "Variation in the essential oil composition of Artemisia annuaL. of different origin cultivated in Finland," Flavour and Fragrance Journal, vol. 12, pp. 241-246, 1998.

[69] A. I. Hussain, F. Anwar, P. S. Nigam, M. Ashraf, and A. H. Gilani, "Seasonal variation in content, chemical composition and antimicrobial and cytotoxic activities of essential oils from four Mentha species," Journal of the Science of Food and Agriculture, vol. 90, no. 11, pp. 1827-1836, 2010.

[70] A. R. Duarte, R. R. Naves, S. C. Santos, J. C. Seraphin, and P. H. Ferri, "Genetic and environmental influence on essential oil composition of Eugenia dysenterica," Journal of the Brazilian Chemical Society, vol. 21, no. 8, pp. 1459-1467, 2010.

[71] H. Sadeghi, S. Jamalpoor, and M. H. Shirzadi, "Variability in essential oil of Teucrium polium L. of different latitudinal populations," Industrial Crops and Products, vol. 54, pp. 130-134, 2014.

[72] D. Kremer, S. Bolarić, D. Ballian et al., "Morphological, genetic and phytochemical variation of the endemic Teucrium 
arduini L. (Lamiaceae)," Phytochemistry, vol. 116, pp. 111-119, 2015.

[73] G. Ruberto and M. T. Baratta, "Antioxidant activity of selected essential oil components in two lipid model systems," Food Chemistry, vol. 69, no. 2, pp. 167-174, 2000.

[74] W. Wang, N. Wu, Y. G. Zu, and Y. J. Fu, “Antioxidative activity of Rosmarinus officinalis L. essential oil compared to its main components," Food Chemistry, vol. 108, no. 3, pp. 1019-1022, 2008.

[75] M. A. Rather, B. A. Dar, M. Y. Dar et al., "Chemical composition, antioxidant and antibacterial activities of the leaf essential oil of Juglans regia L. and its constituents," Phytomedicine, vol. 19, no. 13, pp. 1185-1190, 2012.

[76] E. Aydin, H. Türkez, and F. Geyikoğlu, "Antioxidative, anticancer and genotoxic properties of $\alpha$-pinene on N2a neuroblastoma cells," Biologia, vol. 68, no. 5, pp. 1004-1009, 2013.

[77] M. Shahriari, A. Zibaee, N. Sahebzadeh, and L. Shamakhi, "Effects of $\alpha$-pinene, trans-anethole, and thymol as the essential oil constituents on antioxidant system and acetylcholine esterase of Ephestia kuehniella Zeller (Lepidoptera: Pyralidae)," Pesticide Biochemistry and Physiology, vol. 150, pp. 40-47, 2018.

[78] L. G. D. L. Guimarães, M. D. G. Cardoso, P. E. D. Sousa, J. D. Andrade, and S. S. Vieira, "Atividades antioxidante e fungitóxica do óleo essencial de capim-limão e do citral," Revista Ciência Agronômica, vol. 42, no. 2, pp. 464-472, 2011.

[79] E. Sarrou, P. Chatzopoulou, K. Dimassi-Theriou, and I. Therios, "Volatile constituents and antioxidant activity of peel, flowers and leaf oils of Citrus aurantium L. Growing in Greece," Molecules, vol. 18, no. 9, pp. 10639-10647, 2013.

[80] C. Shi, X. Zhao, Z. Liu, R. Meng, X. Chen, and N. Guo, "Antimicrobial, antioxidant, and antitumor activity of epsilon-poly-L-lysine and citral, alone or in combination," Food and Nutrition Research, vol. 60, pp. 3-89, 2016.

[81] K. E. Heim, A. R. Tagliaferro, and D. J. Bobilya, "Flavonoid antioxidants: chemistry, metabolism and structure-activity relationships," The Journal of Nutritional Biochemistry, vol. 13 , no. 10 , pp. 572-584, 2002.

[82] M. M. Tajkarimi, S. A. Ibrahim, and D. O. Cliver, "Antimicrobial herb and spice compounds in food," Food Control, vol. 21, no. 9, pp. 1199-1218, 2010.

[83] M. S. Tounsi, W. A. Wannes, I. Ouerghemmi et al., "Juice components and antioxidant capacity of four Tunisian Citrus varieties," Journal of the Science of Food and Agriculture, vol. 91, no. 1, pp. 142-151, 2011.

[84] M. N. Alam, N. J. Bristi, and M. Rafiquzzaman, "Review on in vivo and in vitro methods evaluation of antioxidant activity," Saudi Pharmaceutical Journal, vol. 21, no. 2, pp. 143-152, 2013.

[85] S. Cosentino, C. I. G. Tuberoso, B. Pisano et al., "In-vitro antimicrobial activity and chemical composition of Sardinian Thymus essential oils," Letters in Applied Microbiology, vol. 29, no. 2, pp. 130-135, 1999.

[86] I. Karaman, F. Sahin, M. Güllüce, H. Ogütçü, M. Sengül, and A. Adigüzel, "Antimicrobial activity of aqueous and methanol extracts of Juniperus oxycedrus L," Journal of Ethnopharmacology, vol. 85, no. 2-3, pp. 231-235, 2003.

[87] F. Sahin, I. Karaman, M. Güllüce et al., "Evaluation of antimicrobial activities Satureja hortensis L," Journal of Ethnopharmacology, vol. 87, no. 1, pp. 61-65, 2002.

[88] J. M. Kim, M. Marshall, J. A. Cornell, J. F. P. Iii, and C. I. Wei, "Antibacterial activity of carvacrol, citral, and geraniol against Salmonella typhimurium in culture medium and on fish cubes," Journal of Food Science, vol. 60, no. 6, pp. 1364-1368, 1995.

[89] S. Inouye, T. Takizawa, and H. Yamaguchi, "Antibacterial activity of essential oils and their major constituents against respiratory tract pathogens by gaseous contact," Journal of Antimicrobial Chemotherapy, vol. 47, no. 5, pp. 565-573, 2001.

[90] H. J. D. Dorman and S. G. Deans, "Antimicrobial agents from plants: antibacterial activity of plant volatile oils," Journal of Applied Microbiology, vol. 88, no. 2, pp. 308-316, 2000.

[91] N. Filipowicz, M. Kami?ski, J. Kurlenda, M. Asztemborska, and J. R. Ochocka, "Antibacterial and antifungal activity of juniper berry oil and its selected components," Phytotherapy Research, vol. 17, no. 3, pp. 227-231, 2003.

[92] K. Sato, S. Krist, and G. Buchbauer, "Antimicrobial effect of trans-cinnamaldehyde, (-)-Perillaldehyde, (-)-Citronellal, citral, eugenol and carvacrol on airborne microbes using an airwasher," Biological and Pharmaceutical Bulletin, vol. 29, no. 11, pp. 2292-2294, 2006.

[93] A. M. Leite, E. D. O. Lima, E. L. D. Souza, M. D. F. F. M. Diniz, V. N. Trajano, and I. A. D. Medeiros, "Inhibitory effect of beta-pinene, alpha-pinene and eugenol on the growth of potential infectious endocarditis causing Gram-positive bacteria," Revista Brasileira de Ciências Farmacêuticas, vol. 43, no. 1, pp. 121-126, 2007.

[94] A. A. Saddiq and S. A. Khayyat, "Chemical and antimicrobial studies of monoterpene: Citral," Pesticide Biochemistry and Physiology, vol. 98, no. 1, pp. 89-93, 2010.

[95] W. Wang, N. Li, M. Luo, Y. Zu, and T. Efferth, “Antibacterial activity and anticancer activity of Rosmarinus officinalis L. Essential oil compared to that of its main components," Molecules, vol. 17, no. 3, pp. 2704-2713, 2012.

[96] Y. Wang, X. Zeng, Z. Zhou et al., "Inhibitory effect of nerol against Aspergillus niger on grapes through a membrane lesion mechanism," Food Control, vol. 55, pp. 54-61, 2015.

[97] S. Barel, R. Segal, and J. Yashphe, "The antimicrobial activity of the essential oil from Achillea fragrantissima," Journal of Ethnopharmacology, vol. 33, no. 1-2, pp. 187-191, 1991.

[98] A. K. Tyagi and A. Malik, "Antimicrobial potential and chemical composition of Eucalyptus globulus oil in liquid and vapour phase against food spoilage microorganisms," Food Chemistry, vol. 126, no. 1, pp. 228-235, 2011. 